\title{
Effects of operational performance on financial performance
}

\author{
Jinpyo Lee a* $^{*}$
}

${ }^{a}$ College of Business Administration, Hongik University, Seoul, Republic of Korea

\begin{tabular}{|c|c|}
\hline CHRON I C L E & A B S T RACT \\
\hline $\begin{array}{l}\text { Article history: } \\
\text { Received: September 5, } 2018 \\
\text { Received in revised format: Octo- } \\
\text { ber } 8,2018 \\
\text { Accepted: November 7, } 2018 \\
\text { Available online: } \\
\text { November 7, 2018 } \\
\text { Keywords: } \\
\text { Operations Performance } \\
\text { Supply Chain } \\
\text { Return on invested capital } \\
\text { (ROIC) tree } \\
\text { Productivity Ratio } \\
\text { Airline Industry }\end{array}$ & $\begin{array}{l}\text { Over the past } 40 \text { years, global air travel has increased eight-fold: In } 1974 \text { air planes carried } 421 \\
\text { million people globally. This means that global air travel has been growing up about } 5 \% \text { every year } \\
\text { for } 4 \text { decades and this trend is expected to continue in the future. While demand growth is an im- } \\
\text { portant factor for the profitability of the airline industry, its impact quite depends on the operational } \\
\text { performances such as load factor, passenger yield, labor efficiency and fuel efficiency. So, the ob- } \\
\text { jective of this study is to analyze companies competing in the airline industry to address how to use } \\
\text { the return on invested capital (ROIC) tree model to analyze the effect of operational performances } \\
\text { on airline companies' financial performance and then how to increase the financially inferior com- } \\
\text { pany's performance by intimidating the operationally and financially superior and productive com- } \\
\text { pany. In the case of the Korean airline industry, two leading legacy airline companies called as a } \\
\text { company A and B were selected to do the computational study for the effect of operational perfor- } \\
\text { mance on the financial performance and productivity. We analyzed the financially high-performing } \\
\text { company using the ROIC tree model and then looked at financially how much the inferior company } \\
\text { would be improved if it could imitate some factor consisting of the productivity ratios from the } \\
\text { financially high-performing company. }\end{array}$ \\
\hline
\end{tabular}

\section{Introduction}

Over the last 40 years, the global air travel has almost increased eight-fold: In 1974 air planes carried 421 million people globally (Schuttenhelm, 2016). This means that global air travel has been growing up about $5 \%$ every year for 4 decades and this trend is expected to continue in the future. While demand growth is an important factor for airline company's profit, its impact on its profitability quite depends on the operational performances such as load factor, passenger yield, labor efficiency and fuel efficiency which are nomenclatures in the airline industry and rigorously defined later. For this end, a return on invested capital (ROIC) tree model is suggested in this study to analyze the link between the operational performance variables and the financial performance. ROIC stands for Return on invested capital and is a value calculated to evaluate a company's financial efficiency when allocating the invested capital under its control to profitable investments. It also shows a sense of how well a company uses its money to generate returns. Comparing a company's return on invested capital with its weighted average cost of

* Corresponding author.

E-mail address: jinpyo.lee@hongik.ac.kr (J. Lee) 
capital (WACC) reveals whether invested capital is being used effectively which is defined as an economic value as follows (Cachon \& Terwiesch, 2008),

$$
\text { Economic Value created = Invested Capital } \times(\text { ROIC }-W A C C),
$$

where WACC is the discount factor which represents the risk faced by the investor, and blends the required rates of return for debt $\left(k_{d}\right)$ and equity $\left(k_{e}\right)$ based on the company's market-based value (Koller et al., 2010). WACC is given as follows

$$
W A C C=\frac{D e b t}{\text { Debt }+ \text { Equity }} k_{d}\left(1-T_{m}\right)+\frac{\text { Debt }}{\text { Debt }+ \text { Equity }} k_{e},
$$

where $T_{m}$ is the marginal tax rate and is deducted for the interest tax shield. Since all the value in WACC and invested capital are exogenously given, now we have a chance to increase the economic value created only by increasing the ROIC. This logic leads us to focus on the ROIC in this study.

\section{Literature Review}

Many traditional literatures on measuring the effect of the operational performance on the financial performance issue have dealt with the effect of specific operational variable on the financial performance. However, little attention is given to the effect of various operational variables and productivity index on the financial performance. Belobaba et al. (2015) comprehensively included the cost structure and productivity for airline company. They categorized the operating cost functionally into fuel cost, direct labor cost, depreciation cost and maintenance cost and moreover suggested the cost driver for each category which also explained in the line of productivity index. Gillen et al. $(1985,1990)$ measured and compared the productive performance of seven Canadian air carriers during 1964-81 by analyzing total factor productivity (TFP) and total cost functions. Ferguson et al. (2013) described the development of an airline cost model, based on the Eurocontrol model, which explicitly identified the components of airline costs for US airline cost data including 111 aircraft types. Zou and Hansen (2012) developed and incorporated two distinct sets of operational performance metrics into the airline cost models as arguments. Their results from estimating a variety of airline cost models showed that both delay and schedule buffer are important cost drivers. Lee (2011) introduced the multiple period inventory control problem of a single product with multiple (two) prices, depending on service level, in which it showed the effect of pricing and ordering decisions on the company's financial performance such as profit. Barros and Couto (2013) used the Luenberger productivity indicator to evaluate productivity changes of European airlines, combining operational and financial variables from 2000 to 2011 . Na et al. (2016) considered an inventory system where there were some random demands from customers as well as unreliable supplying capacity from supplier and showed the effect of pricing and ordering decisions on the company's financial performance using the dynamic programming model. Duke and Torres (2005) suggested the computational result that the multifactor productivity is annual $2.0 \%$ increases in US airlines using the

data during 1972-2001 period. As shown in the above studies, traditional works have focused on the effect of a particular operational variable on the financial performance in the airline industry. However, the link between various operational variables including productivity and financial performance has not been addressed in the previous works. There are few studies in which ROIC tree model is used for the analysis of link between the operational performance variables and the financial performance in other industries. Min and Chang (2014) suggested ROIC tree model to analyze operations performance of supply chain for farm product. Kim and Kim (2018) suggested a ROIC tree model to analyze the profitability of coffee franchise companies in Korea. As shown above, many previous literatures in the effect of the operational performance on the financial performance issue have dealt with the effect of specific operational variable on the financial performance. However, little attention is given to the effect of various operational variables and productivity index on the financial performance. So, to the best of our knowledge, there is no study for a model which consider the effect of various operational variables and 
productivity index on the financial performance in the airline industry. So, it is pretty much new and will bridge the research gap between the operational performance and financial performance.

In Section 3, we discuss the concept of ROIC model and how to expand it up to the operational variables in the airline industry. In Section 4, we present the results of simulation experiments using the financial data from Korean airline companies, and in Section 5, we will present conclusions.

\section{Method}

\subsection{Notations}

1. Available seat miles (ASM) or Available seat kilometers (ASK): Capacity carrying passenger. (number of seats available $) \times($ number of miles or kilometers flown)

2. Equity: Value left over for shareholders when a company would utilize its assets to meet its liability obligations. Asset - Debt

3. Fixed Capital: Capital which are necessary to start up and conduct business, even at a minimal stage

4. Working Capital: Capital available to a company for day-to-day operations

5. Invested Capital: Fixed Capital + Working Capital

6. Load Factor (LF): RPM /ASM

7. Passenger Yield (PY): Measure of average fare paid per mile, per passenger or cargo. Revenue/RPMs

8. Selling, General \& Administrative expense (SG\&A): Sum of all direct and indirect selling expenses and all general and administrative expenses of a company

9. Return: Money made or lost on an investment. Revenue - Total cost

10. Return on Asset (ROA): Measure of how profitable a company is relative to its total assets. Return/Asset

11. Return on Equity (ROE): Measure of the profitability of a business in relation to the equity. Return/Equity

12. Return on Invested Capital (ROIC): Measure of company's profitability and value-creating potential after taking into account the amount of initial capital invested. Return/Invested Capitial

13. Revenue Passenger Miles (RPMs) and Revenue Passenger Kilometers (RPKs): Measure of traffic for an airline flight, bus, or train.

(number of revenue paying passengers aboard the vehicle $) \times($ distance traveled)

14. Total Cost: Actual cost incurred on the resources to obtain a certain level of output. Fixed Cost + Variable Cost

15. Working Capital: Capital available to a company for day-to-day operations

16. Weighted Average Cost of Capital (WACC): Market-based weighted average of the after-tax cost of debt and equity

17. $k_{d}$ : Required rates of return for debt based on the company's market-based value.

18. $k_{-} e$ : Required rates of return equity based on the company's market-based value.

19. $T_{m}$ : Marginal tax rate

\subsection{Concept of ROIC Tree Model}

Return on assets (ROA), return on equity (ROE) and return on invested capital (ROIC) are the three most prevalent metrics used to obtain an idea of the returns a company generates, and to compare this return generation to the company's peers (Min \& Chang, 2014, Koller et al., 2010). ROA can be skewed when a company holds excess amount of cash or assets for sale. These assets, while not expected to generate profit, are considered to cause ROA to appear lower than that which the company's actual productive assets generate. Also, as Equity = Assets - Liabilities, the more liabilities a company has in its capital structure the smaller the equity will be as a percentage of total assets. Unlike the ROA metric, which remains stable throughout all capital structures, ROE can appear extremely high or extremely low when comparing a company to another employing a very different percentage of liability to equity. However, 
ROIC is calculated as return (operating profit) divided by invested capital which is defined as the operating net working capital plus operating fixed assets. Operating fixed assets are any assets that are expected to contribute to earnings such as properties, plant, equipment, goodwill, intangible assets, etc. Operating net working capital, which is calculated as account receivables plus inventory minus account payables, ensures that only current assets that are expected to generate earnings are included in the calculation. Thus, ROIC gives a good indication of a company's actual capacity to generate returns through utilization of its productive assets. Basic concept of ROIC tree is to link the financial performance (ROIC) with the corresponding operational values and then to analyze how much the financial performance can be improved if some of the operational values are improved. So, ROIC tree can be thought as a set of tools that can analyze the operational performance of a company and be used to measure how much the economic value of the company can be created through the improvement of its operation. ROIC tree can be built as follows (Cachon \& Terwiesch, 2008). First, start with the objective value which is measured by ROIC on one side of the tree. Second, decompose a variable of ROIC into its operational components. Third, decide which branches of the tree have important impact. Forth, expand important branches and then return to second step. Fifth, end with measures that can be tied to operational strategy. Sixth, populate the tree with actual numbers. Finally, reflect on the tree to see if it makes sense by doing benchmark performance and sensitivity analysis.

\subsection{ROIC Tree expanded up to operational variables}

Suppose that the manager in the company wants to improve the ROIC and wants to know what operations in the company need to be improved. For this end, using the Dupont expansion model, the ROIC can first be manipulated as follows

$$
\text { ROIC }=\frac{\text { Return }}{\text { Invested Capital }}=\frac{\text { Return }}{\text { Revenue }} \times \frac{\text { Revenue }}{\text { Invested Capital }},
$$

where the first term is the margin and the second term is the capital turns. To measure each value in the ROIC Dupont model, we need to extract the invested capital from balance sheet and the return from income statement. The invested capital is operating net working capital plus operating fixed assets and the return is the operational profit which is the profit generated by the company's core operations (Koller et al, 2010). Now, we need the following nomenclatures to expand the ROIC up to the more practical operational variables for the airline industry. (MIT Global Airline Industry Program, 2013) First, Revenue Passenger Miles (RPMs) and Revenue Passenger Kilometers (RPKs) is measure of traffic for an airline flight, bus, or train calculated by multiplying the number of revenue-paying passengers aboard the vehicle by the distance traveled. Second, Available seat miles (ASM) or Available seat kilometers (ASK) is passenger carrying capacity, which is equal to the number of seats available multiplied by the number of miles or kilometers flown and is the fundamental unit of production for a passenger-carrying airline. Third, Load Factor(LF) is defined as the ratio RPM / ASM. Finally, Passenger Yield(PY) is measure of average fare paid per mile, per passenger or cargo, calculated by dividing revenue by revenue passenger miles (RPMs). Now, the annual return for the airline company can be calculated as follows,

$$
\text { Return }=\text { Revenue }- \text { Fixed Cost }- \text { Variable Cost }=\text { Revenue }-(\text { SG\&A + Labor Cost })-\text { Fuel Cost } .
$$

The major variable cost for the airline company is fuel cost and the fuel cost can be expanded using ASMs as follows.

$$
\text { Fuel Cost }=\frac{\text { Fuel Cost }}{A S M} \times A S M=\frac{\text { Fuel Cost }}{\text { Fuel Amount Used }} \times \frac{\text { Fuel Amount Used }}{A S M} \times A S M,
$$

where the first term is the fuel price per unit gallon the company procures and the second term is the fuel efficiency for the company. So, if the airline company has a buying power for procurement of the fuel at the lower price than other airline companies, then it can have a better stance for the higher return. However, since the rising cost of oil and all airlines are under intense financial pressure, the airline company needs to hedge its fuel costs by trading on the oil futures market. Since the labor cost in the fixed cost is a major concern in airline, it needs to be expanded more in detail and analyzed as follows, 
Lobor Cost $=\frac{\text { Labor Cost }}{A S M} \times A S M=\frac{\text { Labor Cost }}{\text { Emplyees }} \times \frac{\text { Emplyees }}{A S M} \times A S M$.

The first term is annual wages per employee and the second term is efficiency per employee. Even though the annual wages per employee are hard to cut, the efficiency per employee can be improved by regular training program. The revenue also can be expanded using the nomenclatures for the airline industry as follows,

$$
\text { Revenue }=\frac{\text { Revenue }}{R P M} \times \frac{R P M}{A S M} \times A S M=\text { Passenger Yield }(P Y) \times \text { Load Factor }(L F) \times A S M .
$$

Now, we can expand the ROIC using RPMs, ASMs, Load Factor(LF) and Passenger Yield(PY) as follows

$$
\begin{aligned}
& \text { ROIC }=\frac{\text { Return }}{\text { Revenue }} \times \frac{\text { Revenue }}{\text { Invested Capital }}=\left[1-\frac{S G \& A}{\text { Revenue }}-\frac{\text { Labor Cost }+ \text { Fuel Cost }}{\text { Revenue }}\right] \times \frac{\text { Revenue }}{\text { Invested Capital }} \\
& =\left[1-\frac{S G \& A}{\text { Revenue }}-\frac{\frac{\text { Labor Cost }}{\text { Emplyees }} \times \frac{\text { Emplyees }}{A S M} \times A S M+\frac{\text { Fuel Cost }}{\text { Fuel Amount Used }} \times \frac{\text { Fuel Amount Used }}{A S M} \text { ASM }}{\text { Revenue }}\right] \times \frac{\text { Revenue }}{\text { Invested Capital }} \\
& =\left[1-\frac{S G \& A}{P Y \times L F \times A S M}-\frac{\frac{\text { Labor Cost }}{\text { Emplyees }} \times \frac{\text { Emplyees }}{A S M} \times A S M+\frac{\text { Fuel Cost }}{\text { Fuel Amount Used }} \times \frac{\text { Fuel Amount Used }}{A S M} \text { ASM }}{P Y \times L F \times A S M}\right] \\
& \times \frac{P Y \times L F \times A S M}{\text { Invested Capital }}
\end{aligned}
$$

The invested capital can be expanded as follows,

$$
\text { Invested Capital }=\text { Fixed Capital }+ \text { Working Capital }
$$

where the fixed capital and working capital can be written as follows

Fixed Capital $=$ Plane Capital + Plane related Capital + Other Fixed Capital

$$
=\frac{\text { Plane Capital }}{\text { Number of Planes }} \times \text { Number of Planes }+ \text { Plane related Capital }+(\text { Property }+ \text { Plant }+ \text { Equipment })
$$

So, we have

$$
\text { Working Capital }=\text { Account Receivable }+ \text { Inventory }- \text { Account Payable }
$$

$$
\begin{aligned}
\text { Invested Capital } & =\text { Fixed Capital }+ \text { Working Capital }= \\
& =\left[\frac{\text { Plane Capital }}{\text { Number of Planes }} \times \text { Number of Planes }+ \text { Plane related Capital }+(\text { Property }+ \text { Plant }+ \text { Equipment })\right] \\
& +[\text { Account Receivable }+ \text { Inventory }- \text { Account Payable }]
\end{aligned}
$$

Now, the ROIC can be illustrated as in Fig. 1.

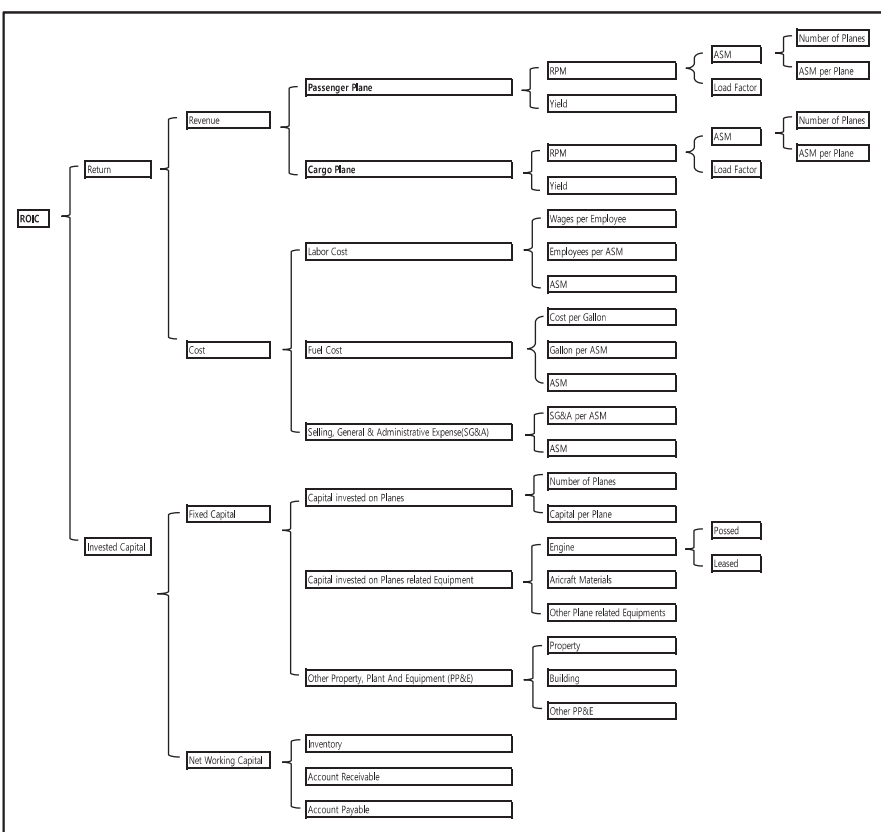

Fig. 1. ROIC tree model expansion for Airline Industry developed for this study 


\section{Numerical Results}

For the computational experiment in this study, the financial data are chosen from two Korean Airline companies. In this computational experiment, we call them as Company A and B. Using the ROIC tree model shown in Fig. 1, we have calculated the ROIC for company A and B, which are $6.83 \%$ and $4.97 \%$, respectively. Then, we have simulated the outcome of ROIC as a function of $10 \%$ improved change in detailed operational variables which are load factor, yield, wages per employee (labor cost), employees per ASM (labor efficiency) and fuel cost per gallon. In both company A and B, as seen in Fig. 2, we can say that the yield and the load factor are the key drivers of financial performance which means that they most highly improve the ROIC compared with the other operational variables. In both company A and $\mathrm{B}$, yield and load factor improve ROIC up to $11 \%$ point. $10 \%$ decrease of fuel cost per gallon improves ROIC up to about $8 \%$ for company A and $6 \%$ for company B. Considering the fluctuation of fuel price being able to put airline company under intense financial pressure, the airline companies might need to hedge its fuel costs by trading on the oil futures market. Employees per ASM (labor efficiency) and wages per employee (labor cost) improve ROIC up to about $7.5 \%$ for company A and 5\% for company B. Load factor is exogenous since it is a function of RPM and thus depends on the customer's demand. So, it is not easy to be improved endogenously by the company. Considering the price competitive market situation in airline industry, yield also is not easy to be controlled by the airline company. However, employees per ASM (labor efficiency) and wages per employee (labor cost) are the variables the airline company can improve endogenously by internal training program.

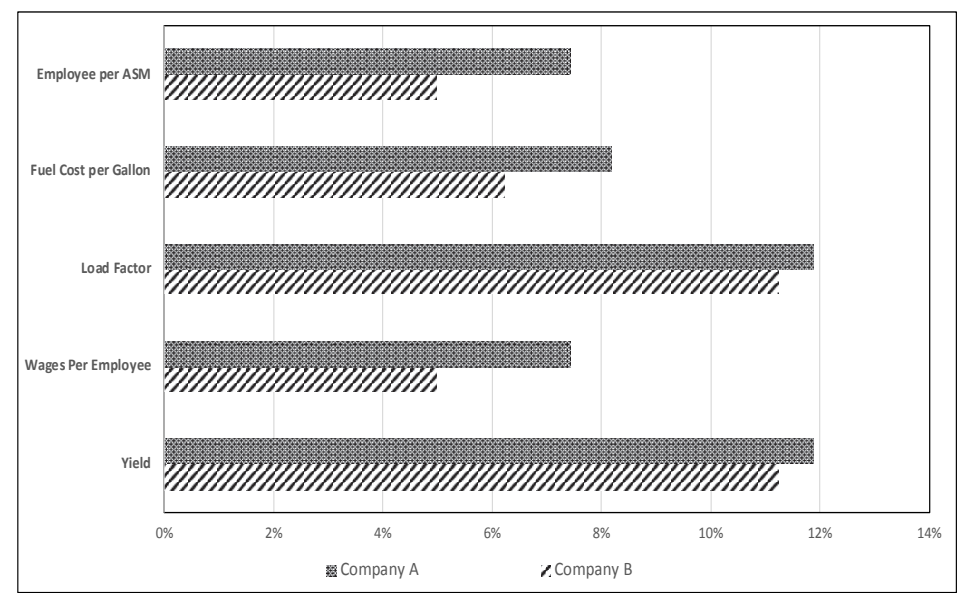

Fig. 2. Simulation Result of ROIC improvement as a function of $10 \%$ change in detailed operational variables

As seen in Fig. 2, the company A has superior ROIC to the company B. Now, we need to analyze the reason why the company A has higher financial performance than the company B. A labor productivity ratio can be suggested as a diagnostic tool (Cachon \& Terwiesch, 2008). It is defined and expanded using the airline nomenclatures as follows

$$
\begin{aligned}
\text { Labor Productivity } & =\frac{\text { Revenue }}{\text { Labor Cost }}=\frac{\text { Revenue }}{R P M} \times \frac{R P M}{A S M} \times \frac{A S M}{\text { Employees }} \times \frac{\text { Employees }}{\text { Labor Cost }} \\
& =\text { Yield } \times \text { Load Factor } \times \frac{A S M}{\text { Employees }} \times \frac{\text { Employees }}{\text { Labor Cost }}
\end{aligned}
$$

Table 1

Labor productivity ratio for company A and B

\begin{tabular}{lccccc}
\hline Company & Labor Productivity & Yield & Load factor & ASM per Employee & Employees per \$1M labor cost \\
\hline A & 11.550 & 0.201 & 0.785 & 4.655 & 15.740 \\
B & 10.310 & 0.176 & 0.826 & 3.716 & 19.050 \\
\hline
\end{tabular}

Even though the company A has lower load factor and higher wages per employee, it offsets its disadvantages with higher yield and labor efficiency (ASM per employee): 
- Considering that the company B has higher load factor, we can say that it has higher customer demand than the company A. This implies that the company has a chance to improve the price so that it would improve its yield. Thus, if the company B could improve its yield as much as the company A could, it could improve its revenue by $9.16 \%$.

$$
\frac{\$ 5,078,963,781-\$ 4,652,792,661}{\$ 4,652,792,661}=9.16 \%
$$

- Suppose that the company B could get as high labor efficiency (ASM per employee) as the company A, which is 4.655 ASM per employee. It takes company B's 8,601 employees to serve $31,960,848,644$ ASM, translating to 3.716 ASM per employees where 3.716 ASM is the value served by employees employed with $\$ 1 \mathrm{M}$. As seen in Table 1 , the company A can serve 4.655 ASM per employees. So, 6,867 employees yields

$$
\frac{31,960,848,644}{4.655 \times 1,000,000}=6,867
$$

which is the number of employees that the company might need if it could achieve the company A's labor efficiency. So, the potential reduction of 1,734 employees would lead to the savings opportunity of

$$
\$ 52,494 \text { per employee } \times 1,734 \text { employees }=\$ 91,024,596
$$

This savings is about $2 \%$ of total cost and $20 \%$ of labor cost which leads to $1.86 \%$ p increase of ROIC from $4.04 \%$ to $5.90 \%$.

\section{Conclusion}

In this study, we have shown that there is a link between the operational variables and the financial performance measure ROIC by doing case study in the airline industry. To many company managers, the corporate finance is rather remote from the operational variables. So, many managers have a difficulty to have confidence for answering question such as "how do we improve company's various operational performance to improve company's the financial performance, like cost savings or increases of product variety?". Thus, in this study we have proposed a ROIC tree model which can analyze the link between the operational variables and financial performance and moreover provide the way to increase the financial performance by improving the company's operations. Using ROIC tree model, we can easily find which operational variable is the key driver of financial performance by simulating the ROIC tree model as a function of same amounts of change in operational variables. In the computational study, we have analyzed two legacy airline companies which are listed in the stock market. We have found that manager could find a chance to obtain cost savings opportunity by improving the operational variables just by internal training program. This is just a starting point for the manager in the company. Since we can only use publicly filing data, we do a top-down analysis using ROIC tree model. However, if managers in the airline company do the same analysis as ours, then they can obtain more detailed data and thus can expand the ROIC tree model into the detailed internal operational variables. This implies that they can have more opportunity to improve the financial performance by improving the internal operational variables.

\section{Acknowledgement}

This work was supported by 2018 Hongik University Research Fund.

\section{References}

Barros, C. P., \& Couto, E. (2013). Productivity analysis of European airlines, 2000-2011. Journal of Air Transport Management, 31, 11-13. 
Birtwistle, G., Moore, C. M., \& Fiorito, S. S. (2006). Apparel quick response systems: the manufacturer perspective. International Journal of Logistics: Research and Applications, 9(2), 157-168.

Belobaba, P., Odoni, A., \& Barnhart, C. (2015). The global airline industry. John Wiley \& Sons.

Cachon, G., \& Terwiesch, C. (2008). Matching supply with demand. McGraw-Hill Publishing.

Duke, J., \& Torres, V. (2005). Multifactor productivity change in the air transportation industry. Monthly Labor Review, 128, 32.

Ferguson, J., Kara, A. Q., Hoffman, K., \& Sherry, L. (2013). Estimating domestic US airline cost of delay based on European model. Transportation Research Part C: Emerging Technologies, 33, 311323.

Gillen, D.W., Oum, T.H., \& Tretheway, M.W. (1985). Airline Cost and Performance: Implications for Public and Industry Policies, Centre for Transportation Studies, University of British Columbia, Vancouver, B.C., Canada

Gillen, D. W., Oum, T. H., \& Tretheway, M. W. (1990). Airline cost structure and policy implications: a multi-product approach for Canadian airlines. Journal of Transport Economics and Policy, 24(1), 9-34.

Kim, T.H., \& Kim, H.S. (2018). A study on the profitability of coffee franchise firms using ROIC Tree, ROA \& ROE. Culinary Science \& Hospitality Research 24(1), 130-139.

Koller, T., Goedhart, M., \& Wessels, D. (2010). Valuation: measuring and managing the value of companies (Vol. 499). John Wiley and sons.

Lee, J. (2011). Inventory control by different service levels. Applied Mathematical Modelling, 35(1), 497-505.

Massachusetts Institute of Technology Global Airline Industry Program. "Airline Data Project: Glossary" Retrieved March 15, 2013.

Min, C. K., \& Chang, B. Y. (2014). Evaluation of operations performance of agricultural products supply chain using ROIC tree. Journal of the Korea Society for Simulation, 23(4), 121-129.

Na, B., Lee, J., \& Ahn, H. J. (2016). Inventory Control by Multiple Service Levels under Unreliable Supplying Condition. Mathematical Problems in Engineering, 2016.

Ramdas, K., Williams, J., \& Lipson, M. (2013). Can financial markets inform operational improvement efforts? Evidence from the airline industry. Manufacturing \& Service Operations Management, 15(3), 405-422.

Schuttenhelm, R. (2016). Take a look at this graph: Global air travel increased 8 fold in 4 decades - and it's an accelerating trend. Yes we have a problem. Retrieved from http://www.bitsofscience.org/graphglobal-air-travel-increase-6848/

Zou, B., \& Hansen, M. (2012). Impact of operational performance on air carrier cost structure: evidence from US airlines. Transportation Research Part E: Logistics and Transportation Review, 48(5), 10321048.

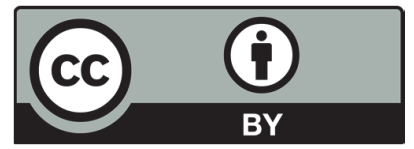

C 2019 by the authors; licensee Growing Science, Canada. This is an open access article distributed under the terms and conditions of the Creative Commons Attribution (CCBY) license (http://creativecommons.org/licenses/by/4.0/). 